\title{
NILAI KEROHANIAN DALAM TUTURAN TRANSAKSI JUAL-BELI BERBAHASA BANJAR DI HULU SUNGAI NAGARA
}

\author{
Rissari Yayuk \\ Balai Bahasa Provinsi Kalimantan Selatan \\ Pos-el: yrissariyayuk@yahoo.co.id
}

\begin{abstract}
A bstrak
Nilai kerohanian adalah salah satu nilai yang lahir melalui proses yang panjang dalam sebuah masyarakat yang memiliki budaya beradab. Salah satu unsur nilai kerohanian adalah nilai moraI. Nilai ini biasanya ditemukan dalam ragam karya sastra. Penelitian mengkaji nilai kerohanian dengan objek yang berbeda, yaitu dalam tuturan lisan pada transaksi jual-beli sebuah pasar di Kalimantan Selatan, Pasar Nagara, di Hulu Sungai Selatan.Teori yang digunakan adalah berhubungan dengan nilai kerohanian yang salah satunya unsur pembangunnya dari nilai moral. Metode yang digunakan adalah deskriptif. Teknik pengumpulan data adalah dokumentasi dan rekam.Hasil penelitian dalam tuturan transaksi jual-beli ini ditemukan nilai kejujuran, mandiri, tolong-menolong, dan kepedulian. Hal ini membuktikan bahwa nilai positif dalam kehidupan tidak hanya dapat digali dari karya sastra semata, tapi teori kesastraan yang berkaitan dengan nilai kerohanian ini dapat diterapkan dalam tuturan lisan sehari-hari, salah satunya pasar yang terdapat di tengah masyarakat.
\end{abstract}

Kata kunci: nilai, kerohanian, transaksi

\begin{abstract}
Spiritual value is one of the values that were born through a long process in a society that has a civilized culture. O ne element of spiritual values is moral value. This value is usually found in a variety of literary works. The present study is to examinetheissue of spiritual valuewith different objects, namely theoral at a market in South Kalimantan, $\mathrm{N}$ agara $\mathrm{M}$ arket, at U pper South River. Thetheory used was related to spiritual values, one of which elements of the builder of moral values. Themethod used was descriptive. $D$ ata collecting techniques were documentating and recording. Theresults of research arethat in speech of buying and selling is found the values of honesty, self-contained, hel ping, and caring. This proves that the positive values in life not only can be extracted from theliteratureal one, but literary theory related to spiritual values can beapplied in everyday oral speech, one of which markets are in the community.
\end{abstract}

Keywords: values, spirituality, transactions

\section{PEN DAHULUAN}

Nilai kerohanian adalah bagian dari nilai budaya yang dimiliki sebuah masyarakat. Sebagai sebuah nilai yang berakar dari budaya masyarakat, nilai kerohanian mengandung nilai-nilai penting dalam kehidupan bermasyarakat yaitu nilai moral dan nilai religi. Notonegoro (dalam Kaelan, 2010:6) menyatakan bahwa nilai moral lahir dari hati nurani atau rohani individu. Nilai moral dalam kehidupan bersumber pada unsur kehendak manusia (susila). Manusia yang bermoral adalah manusia yang beradab. Menurut Qadtratilah (2009:477) religi adalah agama; kepercayaan. Koentjaraningrat (2014:81) menyatakan bahwa religi berkaitan dengan ke percayaan terhadap gagasan yang berkaitan dengan kereligiusan.

Di era globalisasi sekarang, masalah nilai mengalami pergeseran. $\mathrm{Hal}$ ini akibat pengaruh 
arus modern yang mampu menyingkirkan nilai-nilai yang positif dan bermanfaat bagi kehidupan. Arus modern telah membawa pengaruh yang mengkhawatirkan bagi masyarakat luas, terlebih bagi generasi muda.

Nilai dipengaruhi juga masyarakat, agama, dan orang tua. (Nurfaidah, 2015:77). Penting sekali peran ketiga lembaga pendidikan ini untuk mengajarkan akan nilai dalam kehidupan. Nilai kerohanian merupakan ajaran yang patut dibudayakan bagi generasi sekarang maupun akan datang.

Berdasarkan hal ini, penting sekali dilakukan ragam upaya untuk melestraikan masalah nilai dalam kehidupan. Salah satu caranya adalah melalui penelitian dari berbagai peristiwa kehidupan yang melibatkan masyarakat secara luas. Melalui penelitian akan didapatkan fakta dan bahan dokumentasi yang bisa dijadikan referensi dalam menanamkan nilainilai dalam kehidupan bermasyarakat dan bernegara.

Akhir-akhir ini banyak peneliti yang me ngupas mengenai nilai kerohanian yang berwujud nilai moral dalam kehidupan (lihat Hariyanto, 2014; Triastuti, 2012; Yulianto, 2012, dII). Para peneliti ini mengkaji tentang nilai moral yang terdapat dalam karya-karya sastra yang mereka jadikan objek penelitiannya masing-masing. Hariayanto misal nya mengkaji nilai moral dalam cerita rakyat masyarakat Kalimantan Timur dengan judul Kisah Ayus dan Silug. Cerita ini memiliki nilai etos kerja, kearifan dan kasih sayang. Triastuti mengkaji nilai-nilai budi pekerti dalamfabel Banjar. Hasil penelitiannya ini menyatakan bahwa fabel Banjar memiliki nilai budi pekerti yang antara Iain meliputi kasih sayang, hormat menghormati, kejujuran, tolong menolong, dll. Yulianto mengkaji tentang sastra Madihin di Kalimantan Selatan. Nilai moral yang terdapat dalam sastra Madihin antara lain meliputi etos kerja, kerja sama, kasih sayang, dll.

Sementara itu Nengsih (2015) meneliti tentang gambaran kereligiusan orang Banjar dalam Mantra Banjar. Nengsih menemukan dalam mantra Banjar tergambar aspek nilai religi masyarakat Banjar yang meliputi hubungan manusia dengan manusia, hubungan manusia dengan Tuhan, dan hubungan manusia dengan dirnya sendiri.

Keempat penelitian di atas adalah sebagian kecil contoh penelitian yang mengkaji tentang salah satu nilai kerohanian berupa nilai moral dan religi. Objek penelitiannya pun adalah sastra lisan dan tertulis. Penelitian tentang nilai kerohanian yang berbentuk nilai kerohanian dalam tuturan nonfiksi secara lisan jarang dilakukan. Padahal nilai moral dalam kehidupan tidak saja dapat dibaca atau dikaji dari wacana sastra semata, akan tetapi justru dari peristiwa tuturan sehari-hari tentu akan dapat pula kita gali dan kita manfaatkan sebagai salah satu materi yang bernilai positif. Selain itu, nilai kerohanian yang berwujud nilai moral dalam karya sastra berupa cerita rakyat, fabel, dan sastra madihin tersebut sebenarnya secara logika sudah pasti mengandung nilai yang bermanfaat, sebab dia diciptakan untuk memberikan nasihat kepada pendengar atau generasi berikutnya. Berbeda halnya dengan peristiwa tutur sehari-hari yang memiliki konteks dengan tujuan masing-masing, salah satunya dalam transaksi jual-beli yang jelas tujuannya lebih memperhitungkan untung-rugi dibandingkan sastra yang tujuannya adalah memberikan hiburan sekaligus memberikan ragam nasihat bernilai.

Adapun masalah yang akan dikaji dalam penelitian ini meliputi bagaimana wujud nilai moral dalam tuturan transaksi jual-beli berbahasa banjar di hulu sungai nagara dan bagaimana wujud nilai religi dalam tuturan transaksi jual-beli berbahasa banjar di hulu Sungai Nagara. Tujuan yang ingin dicapai adalah mendeskripsikan nilai kerohanian berwujud nilai moral dan religi dalam tuturan transaksi jual-beli berbahasa Banjar di hulu Sungai Nagara. Ruang lingkup penelitian adalah khusus pada penggunaan tuturan masyarakat 
Banjar yang terdapat pada peristiwa transaksi di Pasar N agara, Kabupaten H ulu Sungai Selatan.

Kegunaan penelitian bisa dimanfaatkan dalam dunia pendidikan maupun masyarakat umum. Bagi dunia pendidikan, materi ini bisa dijadikan salah satu referensi tentang nilai kerohanian. Bagi masyarakat umum bermanfaat untuk menjadi gambaran dan menambah wawasan tentang pentingnya pelestarian nilai kerohanian dalam kehidupan bermasyarakat di berbagai bidang kehidupan termasuk dalam dunia transaksi.

\section{TEORI DAN METODE}

Secara umum makna nilai adalah kualitas dari suatu yang bermanfaat bagi kehidupan manusia, baik lahir maupun batin. Dalam kehidupan manusia, nilai dijadikan landasan, alasan, dan motivasi dalam bersikap, serta bertingkah laku, baik disadari atau tidak (Kaelan, 2010:92). N ilai dalam Kamus Besar Bahasa Indonesia (KBBI, 2008:963) adalah sifat-sifat (hal-hal) yang penting atau berguna bagi kemanusiaan. Soekanto (2014:532) menyatakan nilai adalah konsep-konsep abstrak yang ada dalam diri manusia, mengenai apa yang dianggap baik dan buruk. Achmad (dalam Nengsih, 2013:13) menyatakan nilai adalah hasil kegiatan rohani yaitu akal dan perasaan. Perasaan memberikan bahan-bahannya dan akal mengolah bahan tersebut.

Dengan demikian, nilai dalam kehidupan manusia berkaitan dengan sikap dan perilaku yang baik. Perilaku tersebut membawa dampak kebaikan bagi orang sekitar. Nilai menjadi salah satu landasan dal am kehidupan manusia. Nilai dalam kehidupan merupakan bagian yang bila dipegang akan membentuk individu yang berkarakter. Jika karakter telah membentuk kepribadian dan bersifat umum, maka karakter yang bernilai akan menjadi bagian dari budaya yang bernilai pula. Samani dan Haryanto ( 2014:41-42) menyatakan karakter adalah cara berpikir dan berprilaku yang khas tiap individu untuk hidup dan bekerja sama baik dalam lingkup keluarga, masyarakat, bangsa, dan negara. Karakter dapat dianggap sebagai nilainilai perilaku yang berhubungan dengan Tuhan Yang Maha Esa, diri sendiri, sesama manusia, lingkungan, dan kebangsaan yang terwujud dalam pikiran, sikap, perkataan, dan perbuatan berdasarkan norma agama, hukum tata karma, budaya, adat istiadat, dan estetika. Karakter ini akan terlihat dalam perilaku sehari-hari baik dalam sikap maupun tindakan. Koentjaraningrat (2014:76) mengatakan bahwa nilai budaya itu adalah tingkat pertama kebudayaan ideal atau adat. Nilai budaya adalah lapisan paling abstrak dan luas ruang lingkupnya. Tingkat ini adalah ide-ide yang mengonsepsikan hal-hal yang paling bernilai dalam kehidupan masyarakat. Selain itu, sistem nilai budaya terdiri atas konsepsi yang hidup dalam alam pikiran sebagian besar warga masyarakat mengenai hal-hal yang harus mereka anggap bernilai dalam kehidupan. Oleh karena itu, suatu sistem nilai budaya biasanya berfungsi sebagai pedoman tertinggi bagi kelakuan manusia. Nilai-nilai budaya yang dapat mendorong pembangunan, khususnya pembangunan watak, adalah gotong-royong, musyawarah, adil, dan suka menolong.

Selanjutnya, N otonegoro (1975:6) membagi nilai dalam tiga kategori: (1) Nilai material, yaitu sesuatu yang berguna bagi unsur manusia; (2) Nilai vital, yaitu segala sesuatu yang berguna bagi manusia untuk melakukan aktivitasnya; (3) Nilai kerohanian, yaitu segala sesuatu yang berguna bagi rohani manusia. Nilai kerohanian ini meliputi nilai keberanian yang bersumber pada unsur rasio manusia, budi, cipta, nilai keindahan yang bersumber pada rasa intuisi, nilai moral yang bersumber pada unsur kehendak manusia (susila), nilai religi yang bersumber pada ketuhanan, merupakan nilai kerohanian tertinggi dan mutlak. Berkaitan dengan penelitian ini, peneliti menggali masalah nilai kerohanian.

Berdasarkan dua pendapat di atas, nilai kerohanianmerupakan salah satu sumber nilai 
yang menjadi budaya manusia yang beradab karena memiliki hati nurani. Nilai ini akan dapat diwujutkan dalam kehidupan seharihari jika individu tersebut memegang teguh aturan agama dan etika masyarakat di sekitarnya. Masyarakat yang memiliki anggota yang bermoral otomatis akan mudah mewujudkan kehidupan yang baik. Kehidupan yang baik tersebut meliputi keadaan atau kondisi yang nyaman, tentram, religius, bersatu, dan bertatakrama. Dalam nilai kerohanian ini secara umum meliputi nilai keberanian, nilai kejujuran, tolong-menolong, religi, peduli, dan nilai moral.

Nilai keberanian merupakan sebuah sikap yang berkaitan dengan kemampuan untuk menyatakan dan melakukan sesuatu tanpa adanya rasa takut. KBBI (2008:176) menyatakan berani adalah mempunyai hati yang mantap dan rasa percaya diri yang besar dalam menghadapi bahaya, kesulitan, tidak takut mengatakan dan tidak takut melakukan. Bryant (2002:20) menyatakan sikap berani adalah sikap yang memungkinkan kita untuk menghadapi kesulitan, bahaya, atau rasa sakit dengan cara yang membuat kita dapat mengendalikan situasi tersebut.

Nilai keberanian merupakan bagian nilai kerohanian yang positif. Nilai ini memiliki kebaikan yang bermanfaat. Nilai keberanian sangat penting dijadikan prinsip dalam kehidupan bermasyarakat dan berbudaya. Namun harus diingat sikap berani jangan sampai merugikan orang Iain. Djojosuroto (2006:13) menyatakan prinsip sikap baik adalah sikap yang tidak merugikan orang lain baik adalah sikap yang dituntut (oleh/ kepada) kita saat berhubungan dengan orang lain. Sikap ini mengajurkan agar kita mengusahakan akibatakibat sebanyak-banyaknya dan sedapatdapatnya akibat buruk dari tindakan kita.

Dengan demikian, nilai keberanian tidak hanya berkaitan dengan perkataan dan perbuatan tanpa perhitungan, akan tetapi ketika melakukan perkataan dan perbuatan berani mesti dipikirkan akibatnya. Sikap berani yang memiliki nilai adalah apabila sikap tersebut membawa manfaat yang baik bagi orang lain.

Berikutnya berkaitan dengan nilai moral. Nilai moral menurut Makmurtomo dkk. (1989: 79) diidentikkan dengan nilai kesusilaan karena bersumber kepada susila manusia itu sendiri yang berkaitan dengan norma, peraturan hidup, perintah, sikap, siasat batin, keadaan perilaku, sopan santun, dan tata krama.

Harianto dkk. (2012:33) menyatakan salah satu wujud nilai moral adalah menyangkut keterlibatan individu dengan lingkungan dan masyarakatnya. Pada aspek individu, ada proses belajar anggota masyarakat untuk mengenal dan menghayati kebudayaan masyarakat dalam lingkungannya. Pada aspek lingkungan dan masyarakat ada upaya bersama untuk mengangkat lingkungan dan masyarakat menjadi lebih baik.

Moral merupakan perbuatan atau tindakan yang dilakukan sesuai dengan ide-ide atau pendapat-pendapat umum yang diterima yang meliputi kesatuan sosial lingkunganlingkungan tertentu (A minuddin, 2009:153). Moral adalah ajaran baik-buruk yang diterima umum menjadi perbuatan sikap kewajiban akhlak budi pekerti dan susila (Nurgiyantoro: 2007:320-321).

Suseno mengatakan (1987:19) bahwa kata moral selalu mengacu pada baik-buruknya manusia sebagai manusia. Norma-norma moral adalah tolak ukur untuk menentukan betul-salahnya sikap dan tindakan manusia dilihat dari segi baik-buruknya.Nilai moral bertolak pada sikap, kelakuan, yang dapat dilihat melalui perbuatan. Suseno (1987:142150) menyebutkan nilai moral meliputi kejujuran, tolong-menolong, bertanggung jawab, keberanian, dan kerendahan hati.

Berdasarkan pendapat di atas, nilai moral merupakan bagian dari sikap atau perilaku individu yang bernilai positif. Nilai moral yang dimiliki seseorang akan membawa dampak baik terhadap diri maupun lingkungannya. Melalui 
nilai moral inilah akan terjalin hubungan masyarakat yang santun, beretika, dan saling menjaga.

Selanjutnya, nilai religi. Nilai ini terdapat dalam perkataan dan perbuatan yang dilandasi kereligiusan. KBBI (2013:1159) menyatakan religi berarti kepercayaan akan adanya kekuatan adikodrati di atas manusia. Mangunwijaya mengatakan (1988:39) agama atau religiusitas menumbuhkan kepekaan. Kepekaan dapat membantu seseorang meraih pengalaman religius dalam menangkap pesan atau tanda tersel ubung yang ada di sekitarnya. Religiusitas merupakan sesuatu yang sangat dalam, yang bersentuhan dengan keinginan seseorang, membutuhkan ketaatan dan memberikan imbalan atau mengingat seseorang dalam masyarakat.

Berdasarkan pendapat di atas. Peneliti me nyimpulakan bahwa nilai kerohanian meliputi nilai moral dan nilai religi. Nilai moral meliputi nilai keberanian, peduli, jujur, dan tolong-me nolong, sedangkan nilai religi adalah nilai yang berkaitan dengan masalah keagamaan. Khusus masalah religi ini berkaitan dengan hubungan manusia dengan manusia, manusia dengan tuhan, dan manusia dengan lingkungan.

Selanjutnya, transaksi jual-beli adalah sebuah aktivitas yang bersifat untung dan rugi dalam sebuah komunitas tertentu. Kegiatan ini sering kita lakukan dalam kehidupan seharihari. Sebagai sebuah kebiasaan yang kita temui, ada kemungkinan besar hal tersebut dirasa bukanlah sesuatu yang istimewa. Padahal jika kita gali lebih dalam berdasarkan teori kesastraan, ada banyak hal yang bisa kita kaji, salah satunya berkaitan dengan nilai kerohanian yang terkandung dalam peristiwa tersebut. Nilai kerohanian ini sangat penting kita dokumentasikan, lestarikan, dan refleksikan dalam kehidupan yang sarat akan nilai negatif di tengah era globalisasi sekarang.

Berdasarkan paparan ini, memang sangat penting untuk menggali nilai kerohanian yang terdapat dalam transaksi jual-beli. D efinisi transaksi menurut Indra Bastian (2006:27) adalah sebagai berikut: "Transaksi adalah pertemuan antara dua belah pihak (penjual dan pembeli) yang saling menguntungkan dengan adanya data/ bukti/ dokumen pendukung yang dimasukkan ke dalamjurnal setelah melalui pencatatan".

Pengertian transaksi menurut Slamet Wiyono (2005:12) adalah sebagai berikut: "Transaksi adalah suatu kejadian ekonomi atau keuangan yang melibatkan paling tidak dua pihak (seseorang dengan seseorang atau beberapa orang lainnya) yang sal ing melakukan pertukaran, melibatkan diri dalam perserikatan usaha pinjam-meminjam dan Iain-lain atas dasar suka sama suka ataupun atas dasar suatu ketetapan hukum/ syariat yang berlaku". Pengertian transaksi (Tim, 2009:621) adalah bisnis, pembicaraan, negosiasi, perundingan.

Berdasarkan pendapat Indra dan Slamet tersebut, transaksi jual-beli akan terjadi jika terdapat dua orang pihak atau lebih saling melakukan pertukaran baik barang atau jasa atas dasar aturan atau hukum tertentu dalam kehidupan sebuah masyarakat.

Berdasarkan pengertian mengenai nilai moral dan transaksi jual-beli, maka tuturan di pasar yang mengandung nilai-nilai yang dimaksud akan dianalisis berdasarkan teoriteori di atas, tapi tetap disesuaikan dengan kondisi di lapangan. Uraian pada bagian pembahasan membuktikan kebenaran pernyataan ini.

Tujuan yang ingin dicapai adalah dapat mendeskripsikan nilai kerohanian yang terdapat dalam transaksi jual-beli di pasar. Data penelitian ini adalah tuturan lisan dari pedagang dan pembeli yang berbahasa Banjar di Pasar Nagara di Hulu Sungai Selatan, Provinsi Kalimantan Selatan. Alasan pemilihan karena di pasar ini ragam pedagang tradisional yang datang dari berbagai kecamatan dan desa yang jauh dari perkotaan turut ambil bagian dalam transaksi jual-beli barang atau jasa. Bahasa Banjar yang mereka gunakan masih relatif asli 
dibandingkan di Ibukota Banjarmasin. Pengaruh masyarakat luar daerah pun tidak begitu besar terhadap budaya lokal mereka. Pasar ini adalah pusat perdagangan terpadu baik transaksi yang terjadi di atas air maupun di darat.

Metode yang digunakan dalam penelitian ini adalah metode deskriptif. Hal ini berarti bahwa penelitian ini dilakukan untuk mendapatkan gambaran yang objektif mengenai nilai kerohanian yang terdapat dalam tuturan transaksi jual-beli di Pasar Nagara, di Hulu Sungai Selatan. Dalam rangka mendeskripsikan penelitian ini, penulis menempuh tiga langkah kerja, yaitu tahap pengumpulan data, pengolahan data, dan tahap penyajian hasil analisis data. Hal ini sesuai pula dengan yang dimaksudkan Sudaryanto (2015:5-8) bahwa dalam metode ini ada tiga, yakni metode pengumpulan data, metode analisis data, dan metode pemaparan hasil analisis keabsahan data. Pendekatan yang digunakan dalam penelitian ini adalah kualitatif dengan hasil analisis deskriptif. Data diklasifikasi dan dianalisis berdasarkan teori yang ada.

Teknik pengumpulan data dengan menggunakan metode simak, baik simak libat cakap (SLC) atau simak bebas libat cakap (SBLC) dengan teknik rekam dan catat. (Mahsun, 2005:92). Sumber masyarakat Banjar di Kandangan Hulu Sungai Selatan. Penelitian dilakukan selama tiga bulan, dari 1 Oktober 2015 s.d. 1 Januari 2015.

\section{HASIL DAN PEMBAHASAN}

Berdasarkan paparan sebelumnya, penelitian ini adalah salah satu upaya yang dilakukan untuk pembuktian bahwa nilai moral me mang masih dapat ditemukan dan dapat terus direfleksikan dalam tuturan lisan, khususnya dalam transaksi jual-beli yang dilakukan oleh pembeli dan pedagang di Pasar Nagara, Hulu Sungai Selatan.

\section{Nilai Moral}

\section{a. Nilai kejujuran}

Kejujuran berhubungan dengan ketulusan hati dan kelurusan hati. Suseno (1987:142143). Nilai kejujuran yang dilakukan oleh salah satu penutur dalam transaksi jual-beli di Pasar Nagara ini berkaitan dengan masalah perasaan penutur untuk peduli terhadap lawan bicara jika dia tidak menceritakan atau mengatakan hal yang sebenarnya. Contoh tuturan yang memiliki nilai kejujuran dapat dilihat dalam tuturan (1) dan (2) di bawah ini.

[1] 27 Cil ae. Rajin 30. Kada larang pang. barangnya hanyar, kuat jua barangnya . M un 20 lain lagi barang. M irip pang. Pasnya 27 sudah dipotongkan.

27 Biasanya 30.Tidak mahal juga. Barangnya baru, lebih bagus juga barangnya. Kalau 20 lain lagi barang. Memamg mirip. Pasnya 27 sudah didiskon.

Kalimat ini diucapkan pedagang setelah terjadi tawar-menawar harga. Pedagang mengatakan bahwa barang yang dijualnya memang baru dan lebih kuat daripada harga yang 20 ribu rupiah. Apa yang dikatakan oleh pedagang ada benarnya. Saat dilihat barang yang dijual memang bagus. Hal ini dapat dilihat dari barang yang harganya lebih rendah yang diperlihatkan pedagang. Dua barang dapat dibandingkan kualitasnya.

Kejujuran pedagang ini sebenarnya akan membawa untung bagi pembeli jika bersedia membelinya dibandingkan jika pembeli mendapatkan barang yang sama di tempat lain namun dengan harga yang lebih mahal, atau sebaliknya mendapatkan barang yang sebenarnya tidak baru dan tidak kuat dengan harga yang lebih mahal.

Berdasarkan konteks ini terlihat dalam budaya jual-beli pada masyarakat Banjar masih memperhatikan pemeliharaan nilai moral. Hal ini dibuktikan pada peristiwa di atas. Pedagang dengan jujur mengatakan apa 
adanya tentang barang yang dijualnya. Memperhatikan hal ini, berarti pedagang telah memegang sebuah nilai yang beradab dalam dirinya. N ilai tersebut menjadi bagian keseharian yang terwujud dalam sikapnya tersebut. Nilai ini memberi manfaat terhadap diri dan lingkungannya. $\mathrm{Hal}$ ini sesuai dengan apa yang dinyatakan Kaelan (2010:92) bahwa nilai adalah kualitas dari suatu yang bermanfaat bagi kehidupan manusia, baik lahir maupun batin. Dalam kehidupan manusia menilai landasan, alasan, dan motivasi dalam bersikap dan bertingkah laku baik disadari atau tidak.

Kejujuran yang dimiliki pedagang pada data [1] telah menunjukkan sikap baik akan keluar dengan sendirinya tanpa memperhitungkan untung-rugi. Sikap baik yang berwujud kejujuran ini merupakan bagian dari nilai moral yang patut dilestarikan dan dimiliki oleh setiap orang dalam menjalin hubungan sosial. A pabila seseorang memiliki sikap baik, otomatis dia berada dalam lingkup perbuatan yang baik. Suseno (1987:19) menyatakan bahwa kata moral selalu mengacu pada baik buruknya manusia sebagai manusia. Normanorma moral adalah tolak ukur untuk menentukan betul salahnya sikap dan tindakan manusia dilihat dari segi baik-buruknya. Nilai moral bertolak pada sikap, kelakuan, yang dapat dilihat melaui perbuatan. Suseno (1987:142-150) menyebutkan nilai moral meliputi kejujuran, tolong-menolong, bertanggung jawab, keberanian, dan kerendahan hati.

\section{[2] Kada bak lagi Ji ai.}

Tidak bagus lagi Ji.

Kalimat ini diucapkan oleh pedagang saat pembeli ingin membeli adas. Sebelumnya pembeli sudah membeli minyak dan gula. Pedagang dengan jujur mengatakan bahwa adas yang dia miliki sudah tidak baik lagi. Padahal jika dia ingin lebih untung lagi, pedagang tersebut bisa saja menjual adas yang dia jual. Pedagang tentu peduli akan perasaan pembeli jika dijual kan adas yang busuk. Selain itu pelanggannya akan tidak kembali lagi jika dia membohongi.

Kejujuran yang dimiliki pedagang ini bisa saja tidak dimiliki pedagang lain. Banyak pengalaman yang mengatakan demikian. Ada pedagang nakal yang memang mencari keuntungan diri sendiri tanpa peduli akan kerugian yang ditanggung orang lain. $\mathrm{Hal}$ ini peneliti saksikan ketika melihat pedagang jagung yang menumpuk jagung dalam beberapa kelompok. Khusus bagian atas tumpukan adalah jagung yang dalam kondisi bagus. Khusus bagian tengah tumpukan adalah bagian jagung yang kondisinya sudah layu dan sedikit busuk.

Sebagaimana data [1], pada data [2] ini menunjukkan adanya salah satu nilai moral yang berwujud kejujuran terdapat dalam aktivitas jual beli. Pedagang memiliki nilai kejujuran yang jika tidak dia tunjukkan kemungkinan besar akan mendapat untung. A kan tetapi, hal itu tidak dilakukannya. Kemungkinan, si pedagang sudah berbudaya akan sikap yang bernilai moral tersebut, sebab sebuah sikap yang baik biasanya adalah dari hasil pembelajaran dari lingkungan. Harianto dkk. (2012:33) menyatakan salah satu wujud nilai moral adalah menyangkut keterlibatan individu dengan lingkungan dan masyarakatnya. Pada aspek individu, ada proses belajar anggota masyarakat untuk mengenal dan menghayati kebudayaan masyarakat dalam lingkungannya. Pada aspek lingkungan dan masyarakat ada upaya bersama untuk mengangkat lingkungan dan masyarakat menjadi lebih baik.

\section{b. Nilai tolong-menolong}

Budaya tolong-menolong dalam transaksi jual-beli dapat dilihat pada data [3] dan [4]

\section{[3] minta tomatnya dua ribu \\ minta tomatnya dua ribu}

Kalimat ini dikatakan pembeli kepada pedagang cabai yang menjual cabainya seharga 
lima ribu satu takar. Akan tetapi, berhubung pembeli cuma ingin membeli dua ribu saja, pedagang pun mempersilakan saja. Pedagang menolong pembeli yang cuma ingin membeli cabai sebanyak dua ribu rupiah, meskipun pedagang biasanya hanya menjual pertakar saja. Pertolongan yang dilakukan pedagang ini menunjukkan adanya nilai tolong-menolong dalam transaksi.

Contoh [3] merupakan salah satu wujud adanya keyakinan pembeli bahwa pedagang akan memberinya pertolongan atas apa yang dimintanya. Pembeli menggunakan kata "minta" dalam ujarannya tersebut. Dia tidak menggunakan nukar 'beli' dalam peristiwa jualbeli tersebut, meskipun dalam keadaan sesungguhnya, peristiwa itu berada dalam lingkup jual-beli. Layaknya sebuah transaksi harusnya memperhitungkan untung-rugi atas barang atau jasa yang diperjual belikan. Namun dalam data [3] ini tidak terjadi. Pengertian transaksi menurut Slamet Wiyono (2005:12) adalah sebagai berikut: "Transaksi adalah suatu kejadian ekonomi atau keuangan yang melibatkan paling tidak dua pihak (seseorang dengan seseorang atau beberapa orang lainnya) yang saling melakukan pertukaran, melibatkan diri dalam perserikatan usaha pinjammeminjam dan lain-lain atas dasar suka sama suka ataupun atas dasar suatu ketetapan hukum/ syariat yang berlaku". D efinisi transaksi menurut Indra Bastian (2006:27) adalah sebagai berikut: “Transaksi adalah pertemuan antara dua belah pihak (penjual dan pembeli) yang saling menguntungkan dengan adanya data/ bukti/ dokumen pendukung yang dimasukkan ke dalam jurnal setelah melalui pencatatan".

Ujaran ini menggunakan kata santun "minta". Kata ini sebagai wujud permintaan tolong agar penjual memenuhi keinginan pembeli. Pembeli memiliki sikap santun dalam berbahasa pada konteks jual-beli ini. Adapun pedagang sebagai pihak yang diminta tolong menyikapinya dengan ramah. Dia memenuhi keinginan pembeli meskipun kemungkinan dia tidak mendapat keuntungan yang diharapkan. Nilai moral berwujud tolong-menolong telah tergambar dalam transaksi ini. Nilai moral yang berkaitan dengan tatanan hidup yang lebih baik dan bermartabat. Nilai moral menurut Makmurtomo dkk. (1989:79) diidentikkan dengan nilai kesusilaan karena bersumber kepada susila manusia itu sendiri yang berkaitan dengan norma, peraturan hidup, perintah, sikap, siasat batin, keadaan perilaku, sopan santun, dan tata krama [4] Salawi haja. Ikam tukari sabarataanlah, nyaman aku bulik.

"D ua puluh lima saja. Kamu beli semuanyalah, enak aku pulang."

Kalimat ini diucapkan oleh pedagang ikan kepada pembeli. Pedagang meminta pembeli untuk membeli semua daganggannya karena dia akan segera pulang. Permintangan tolong pedagang ikan ini ditanggapi segera oleh pembeli. Pembeli mengiyakan apa yang diminta tersebut. A khirnya transaksipun terjadi dengan lancar.

Sikap yang diambil pembeli ikan menunjukkan adanya nilai moral tolong-menolong dalam transaksi. Hal ini membuat pedagang menjadi senang karena dia mendapat untung dua kali, dari laba barang dan cepat pulang akibat dagangannya habis terjual. Sebaliknya pembeli juga mendapatkan keuntungan, dapat ikan banyak dengan harga yang relatif murah.

Sebagaimana data [3], terdapat unsur tolong-menolong dalam transaksi jual-beli ini. Kalau pada data [3] yang meminta tolong adalah pembeli, pada data [4] adalah sebaliknya, yaitu pedagang. Pedagang secara langsung memerintahkan agar pembeli membeli dagangannya semuanya. Alasan yang dikemukakan oleh pedagang agar dia cepat pulang merupakan wujud permintaan tidak langsung.

Dalam budaya transaksi masyarakat Banjar, ujaran seperti data [4] sering ditemukan. Biasanya pedagang hanya menjual modal saja. 
Ujaran ini biasanya juga terjadi kala akan menjelang berakhirnya aktivitas pasar. Jual obral barang pun terjadi.

\section{c. Nilai keberanian}

Keberanian yang ditunjukkan dalam transaksi jual-beli yang dilakukan salah satu penutur adalah berkaitan dengan kemandirian sikap. Sikap ini diambil sebagai wujud dari keinginan untuk tidak ikut pihak lain dalam berpendapat atau berkeinginan yang sama karena sesuatu alasan. Hal ini dapat dilihat pada data [5] dan [6] berikut.

[5] Jangan lagi, itu 4 warna. 4 kali pakai hanyar dibasuh

Jangan lagi, itu 4 warna. 4 kali pakai baru dicuci

Kalimat yang diucapkan pedagang kerudung kepada pembeli ini mengungkapkan bahwa si pedagang bersikeras tidak mau ditawar dengan alasan tertentu. Barang yang dijual pedagang kerudung itu adalah tutup kepala yang berfungsi sebagai pelapis kepala saat memakai kerudung. Pelapis kepala tersebut memiliki kelebihan dibanding pelapis kepala lainnya, yaitu memiliki warna 4 macam. Kelebihan ini disebutkan oleh si pedagang sebagai alasan agar tidak ada tawar menawar Iagi. Keberanian pedagang ini merupakan bagian dari nilai moral yang mesti dijaga agar dia tidak merugi dengan alasan yang tidak begitu jelas akibat mengikuti keinginan pembeli.

Kekuatan hati pedagang untuk bertahan dari harga yang telah dia yakini kepada pembeli membuahkan hasil. Pembeli akhirnya menyetujui transaksi tersebut. Nilai keberanian yang dimiliki pedagang adalah sesuatu yang bernilai positif karena dia tidak bermaksud untuk merugikan atau menjual dengan harga mahal barang yang dia tawarkan, akan tetapi semata-mata memang harga barang itu pada umumnya seperti itu. Hal ini dibuktikan para pedagang lainnya di Pasar Nagara tersebut juga menjual harga yang sama.
Keberanian merupakan bagian dari nilai moral yang pantas dipertahankan. Nilai tersebut sangat menentukan baik-buruknya sebuah keadaan. Contoh dari data [5] ini. Pedagang demi sebuah kebenaran dari apa yang ditawarkannya, dia menjelaskan dengan berani apa yang dia ketahui mengenai barang tersebut. Melalui keberanian pedagang tidak mengalami kerugian, sebab kalau dia tidak berani menjelaskan tentang apa yang terdapat pada dagangannya, mungkin pembeli akan menawar rendah, akibatnya pedagang bisa rugi besar. Keberanian ini adalah sebuah tindakan yang benar dilakukan pedagang. Keberanian yang menjadi bagian nilai moral dari sikap pedagang. Hal ini sesuai dengan apa yang dinyakan Suseno (1987:19) bahwa kata moral selalu mengacu pada baikburuknya manusia sebagai manusia. Norma-norma moral adalah tolak ukur untuk menentukan betul-salahnya sikap dan tindakan manusia dilihat dari segi baik buruknya. Nilai moral bertolak pada sikap, kelakuan yang dapat dilihat melalui perbuatan. Suseno (1987:142150) menyebutkan nilai moral meliputi kejujuran, tolong menolong, bertanggung jawab, keberanian, dan kerendahan hati

[6] Pembeli : Jangan talalu bapilih pang, Cil. Kena hancur jualan ulun.

Jangan terlalu pilih-pilihlah, Bi. Nanti hancur dagangan saya.(1)

Pedagang : U may! Paman ni panyarikan banar.

Aduh! Paman ini pemarah sekali.

Pembeli : Kadanya kayatu, Cilay. M un handak nukar lakasi nyaman kubungkusakan.

(2)

Bukannya seperti itu, Bi. Kalau mau beli cepati supaya kubungkuskan.

Kalimat (1) ini diucapkan dengan tegas oleh pedagang sayur kepada calon pembeli. Keberanian pedagang yang melarang calon pembeli untuk memilih-milih tanpa peduli akan kondisi barang yang dipegang-pegangnya ini 
merupakan panggilan hati penjual untuk segera menyelamatkan daganganya.

Larangan yang dianggap si pembeli sebagai salah satu sifat pemarah penjual sayur bukanlah sebuah kebenaran. Hal ini dibuktikan dengan kalimat (2) berikutnya Kadanya kayatu, Cilay.M un handak nukar lakasi nyaman kubungkusakan. Bukannya seperti itu, Bi. Kalau mau beli cepat supaya kubungkuskan. Makna kalimat ini adalah pedagang menyangkal kalau ucapan sebelumnya adalah bentuk kemarahan akan tetapi sebagai wujud keinginannya agar pedagang lebih berhati-hati dan lebih cepat membeli kemudian pedagang akan segera membungkuskannya. Ketika mengucapkan kalimat klarifikasi ini, nada suara pedagang lebih halus dan rendah dari sebelumnya.

Kalimat Iarangan yang diucapkan pedagang merupakan salah satu wujud keberanian yang terdapat dalam dirinya. Dia tidak ingin dagangannya hancur hanya karena tidak berani menegur pembeli yang memilih secara berlebihan. Pedagang harus menjaga keutuhan dagangannya untuk pembeli berikutnya yang jelas tidak mau membeli jika barang yang dibelinya dalam kondisi yang tidak bagus lagi.

\section{d. Nilai peduli}

Kepedulian akan orang lain masih ditemukan dalam peristiwa transaksi di data [7] dan [8]. Pada kedua data ini menggambarkan akan adanya hubungan emosional antara pedagang terhadap pembeli. Pedagang memperhatikan keadaan pembeli jika akan mengalami kekecewaan setelah selesai bertransaksi. Pedagang pun berupaya untuk memaksimalkan kenyamanan yang bisa dia berikan kepada pembeli.

[7] Handak baplastikkah lagi kada muat nih. Ini na. Jual

Hendak pakai plastikkah lagi tidak muat nih. Ini na. Jual

Ucapan ini dituturkan oleh penjual kepada pembeli. Penjual melihat barang yang dijualnya (nenas) terlihat sangat sesak saat dimasukan dalam plastik. Penjual khawatir jika dengan satu plastik tersebut nenasnya akan jatuh karena plastiknya robek.

Penjual merasa tidak enak hati jika pembeli menjadi kesusahan setelah membeli dagangannya. Penjual menunjukkan rasa perhatiannya tersebut dengan mengucapkan kalimat di atas. Namun sebelumya dia seakan-akan meminta ijin terlebih dahulu kepada pembeli tentang mau-tidaknya si pembeli diberikan plastik satu lagi yang berguna untuk menjadi pelapis bungkusan yang sudah ada.

Selain pertanyaan positif ini, sebenarnya pedagang juga sudah menunjukkan kepeduliannya terhadap baik-tidaknya barang yang dijual nya demi kebaikan penjual dan kelanjutan transaksi berikutnya. Saat pembeli bertanya tentang kualitas barang yang dijual nya, penjual menjawab bahwa semua nenas yang dijualnya dalam kondisi baik. Pedagang tentu berpikir jika dia tidak menjual barang dagangan dengan kualitas yang baik tentu akan mengecewakan pembeli dan transaksi tidak akan berkeIanjutan.

Nilai kepedulian pedagang ini merupakan sesuatu hal yang bernilai tinggi. Artinya, meskipun dalam transaksi biasanya selalu berhubungan dengan untung-rugi, ternyata berdasarkan perbincangan yang terjadi antara pembeli dan penjual nenas terlihat adanya unsur kepedulian. Nilai inilah yang harus tetap dilestarikan dalam kehidupan sehari-hari.

[8] ganali ambil. A mpat hajakah

"ambil yang lebih besar lagi, empat saja"

Pedagang mempersilakan pembeli untuk memilih barang dagangannya. Pedagang seakan-akan tidak merasa rugi sedikitpun atas apa yang akan dilakukan pembeli akibat suruhannya sendiri. Dari sikap pedagang ini menunjukkan bahwa pedagang menginginkan pembeli buah mendapatkan barang dagangan yang sesuai dengan keinginan pembeli, yang besar, bagus, dan matang. 
Data [8] ini menggambarkan wujud nilai moral yang terdapat pada pedagang. Pedagang meskipun untung saja jika pembeli membeli buah yang dijualnya kecil-kecil, tapi dia tidak memperhitungkan hal itu. Terdapat sikap peduli yang tanpa disadarinya merupakan bagian dari nilai moral dalam diri pedagang. $\mathrm{Pe}$ dagang peduli akan keuntungan yang didapatkan oleh pembeli jika memilih buah yang besar dengan kualitas yang bagus.

Data [8] adalah contoh wujud nilai moral yang masih terdapat dalam transaksi jual beli tersebut. Sikap peduli dari pedagang kepada pembeli ini akan menjal in hubungan yang lebih baik antara pedagang dan pembeli. Pembeli menjadi tidak jera membeli dagangan pedagang. Pedagang pun tidak hanya memikirkan untung-rugi dalam transaksi tetapi memperhatikan kualitas barang yang didagangkannya. Nilai moral yang dimiliki pedagang sebagai bagian dari sikapnya tersebut berperan dalam situasi ini. Hal ini sesuai dengan Makmurtomo dkk. (1989:79) yang diidentikkan dengan nilai kesusilaan karena bersumber kepada susila manusia itu sendiri yang berkaitan dengan norma, peraturan hidup, perintah, sikap, siasat batin, keadaan perilaku, sopan santun, dan tata krama. Harianto dkk. (2012:33) menyatakan salah satu wujud nilai moral adalah menyangkut keterlibatan individu dengan lingkungan dan masyarakatnya. Pada aspek individu, ada proses belajar anggota masyarakat untuk mengenal dan menghayati kebudayaan masyarakat dalam lingkungannya. Pada aspek lingkungan dan masyarakat ada upaya bersama untuk mengangkat lingkungan dan masyarakat menjadi lebih baik.

Selanjutnya, sikap peduli ini jika dihubungkan dengan revolusi mental yang digemakan para pemimpin kita, sangatlah mendukung hal tersebut. Revolusi mental berkaitan dengan pembentukan karakter bangsa yang berjiwa bersih dan kuat. Artinya unsur keikhlasan terdapat dalam jiwa merupakan bagian dari revolusi mental. Sikap peduli memiliki unsur keikhlasan tersebut. $\mathrm{H}$ al ini berarti dalam peristiwa transaksi tersebut secara tidak langsung turut memperkokoh gerakan revolusi mental yang sekarang sedang digalakan pemerintah.

\section{Nilai Religi}

Nilai religi terdapat dalam peristiwa transaksi berikut ini menggambarkan bahwa masyarakat Banjar dal am kehidupan ekonominya tidak lepas dari aturan agama mereka, yaitu Islam.

\section{a. Hubungan manusia dengan manusia}

Hubungan manusia dengan manusia di sini maksudnya adalah cara transaksi yang dilakukan antara pedagang dan pembeli yang sesuai dengan ajaran agama. Cara ini dilakukan karena adanya ketaatan antara pedagang dan pembeli terhadap Tuhannya. Berikut contoh yang dimaksudkan tersebut.

\section{[9] Barelaanlah \\ "Relakan ya."}

Data [9] ini diujarkan oleh pedagang kepada pembeli. Latar peristiwa yang terjadi saat itu adalah pedagang baru saja menyerahkan dagangannya yang berupa buah langsat sejumlah dua kilo kepada pembeli. Uang pun sudah diterima pedagang.

Ujaran yang terdapat pada data [9] ini menunjukkan adanya nilai religi berlaku di sini . Pedagang meminta kerelaan hati si pembeli agar bersedia menerima barang yang sudah dibelinya tersebut dengan apa adanya. Artinya pedagang memegang teguh pada ajaran agama yang menganjurkan agar barang yang diperdagangkan mesti diterima dengan kerelaan hati oleh pembeli. A pabila barang yang dijual tersebut dirasa tidak sesuai dan pembeli kecewa akan barang yang dibelinya, akibatnya dosa bisa diterima oleh pedagang.

Unsur religi pada data [9] merupakan gambaran budaya yang berdasarkan agama. Budaya bertransaksi dengan mengujarkan kata 
tersebut dilakukan oleh hampir semua pedagang di pasar maupun di tempat lain dalam kehidupan masyarakat Banjar. $\mathrm{Hal}$ ini menandakan budaya bertransaksi berdasarkan agama begitu membudaya.

Data [9] menggambarkan bahwa pedagang selalu ingat akan anjuran agamanya. Dia mengingat Tuhan dengan segala ajaran dalam agamanya dalam kondisi bertransaksi. Terdapat hubungan religi antara manusia dengan manusia dan antara manusia dengan Tuhan. Pedagang peka akan hubungan tersebut. Dia mewujudkan kereligiusan dalam transaksi itu. Mangunwijaya (1988:39) mengatakan agama atau religiutas menumbuhkan kepekaan. $\mathrm{Ke}$ pekaan dapat membantu seseorang meraih pengalaman religius dalam menangkap pesan atau tanda terselubung yang ada di sekitarnya. Religiusitas merupakan sesuatu yang sangat dalam, yang bersentuhan dengan keinginan seseorang, membutuhkan ketaatan, dan memberikan imbalan atau mengingat seseorang dalam masyarakat.

$$
\begin{aligned}
& \text { [10] Juallah } \\
& \text { "dijual ya" }
\end{aligned}
$$

Data [10] diujarkan oleh pedagang kepada pembeli. Peristiwa yang melatarbelakanginya adalah saat itu pedagang baru saja menyerahkan bungkusan berisi bawang merah sejumlah tiga kilo kepada pembeli. Selesai menyerahnya dagangannya si pedagang pun berujar demikian.

Terdapat unsur religi dalam peristiwa ini. Pedagang menyatakan akad jual-beli . A kad ini menjadi tradisi yang melekat di hampir semua transaksi dalam kehidupan masyarakat Banjar. Mereka akan melakukan akad ini setelah jualbeli atau bertransaksi apa saja.

Data [10] menggambarkan pedagang memiliki ketaatan terhadap agamanya. Dalam agama Islam menganjurkan agar setiap jualbeli diadakan ucapan akad. Ucapan akad yang terdapat dalam data [10] merupakan wujud ajaran tersebut. Pedagang mekipun dalam situasi nonformal dan dalam kondisi bertransaksi, dia tetap taat terhadap anjuran yang terdapat dalam agamanya. Dia tidak ingin menyalahi apa yang sudah diajarkan sebelumnya.

Data [10] merupakan gambaran cara bertransaksi dalam masyarakat Banjar pada umumnya. Biasanya pedagang akan mengatakan ujaran tersebut dengan harapan apa yang dilakukannya diridai oleh Tuhan yang Mahakuasa. A pabila dagangannya dirahmati, maka otomatis kesejahteraan dan rezeki yang halal akan diperolehnya.

Ucapan pedagang ini biasanya juga akan dijawab dengan pembeli dengan ujaran tukar 'beli'. Pernyataan ini untuk melengkapi akad jual-beli yang sudah dilakukan. Antara pedagang dan pembeli percaya akan kebenaran agamanya. Agama yang berasal dari Tuhan dan mengajarkan cara transaksi yang benar. KBBI (2013:1159) menyatakan religi berarti kepercayaan akan adanya kekuatan adikodrati di atas manusia.

\section{b. Hubungan manusia dengan Tuhan}

Hubungan manusia dengan Tuhan berkaitan dengan perkataan dan perbuatan manusia yang berkaitan dengan ketuhanan. Perkataan maupun perbuatan tersebut menunjukkan rasa cinta, rasa keterikatan, dan rasa syukur terhadap Tuhan atas apa yang didapatnya. Contoh hubungan ini dapat dilihat pada bagian berikut.

\section{[11] A lhamdulillah \\ "Alhamdulillah"}

Data [11] ini menunjukkan adanya hubungan antara Tuhan dan manusia tercipta dalam transaksi. Latar peristiwa yang terdapat pada data ini adalah ketika itu pedagang sedang menerima pesanan buah cempedak satu pikap. Mendengar hal tersebut, pedagang langsung mengucapkan ujaran sebagaimana data [11].

Dalam konteks ini digambarkan bahwa pedagang tidak melupakan Tuhan sebagai pemberi rezeki. Pedagang menyatakan rasa 
terima kasihnya kepada Tuhan atas rezeki yang akan diterimanya tersebut dengan mengucapkan syukur. Pedagang percaya akan kekuasaan Tuhan di atas segalanya sebagai pengatur segala sesuatu termasuk dalam hal rezeki di transaksi itu. KBBI (2013:1159) menyatakan religi berarti kepercayaan akan adanya kekuatan adikodrati di atas manusia.

Pedagang sebagai manusia memiliki hubungan dengan Tuhannya. Rasa terima kasih dia ucapkan melalui perkatannya. Rasa percaya akan kekuasaan Tuhan dia lakukan dalam perbuatannya melalui ucapan rasa syukur sebagaimana data [11].

Berdasarkan data [11] dapat menjadi gambaran bahwa pedagang sebagai bagian masyarakat Banjar memiliki budaya taat kepada Tuhannya. Mereka tidak memisahkan antara kehidupan dunia dengan akhirat. Pedagang tidak melupakan Tuhan pemberi rezeki melalui perkataan dan perbuatannya.Contoh [11] ini adalah satu contoh dari sekian banyak contoh lainnya akan adanya bukti pelaksanaan kewajiban manusia terhadap Tuhannya.

[12] A miin

"A min".

Data [12] menunjukkan adanya hubungan manusia dengan Tuhannya. Latar peristiwa yang terdapat pada data [12] ini adalah kala itu pedagang mendapatkan pujian dari pedagang bahwa selama ini barang yang dijualnya sel alu dalam kondisi bagus. Mendengar hal tersebut, pedagang mengucapkan ujaran sebagaimana contoh.

Pedagang merasa bahwa Tuhan lah yang selama ini membuat dagangannya bagus berkualitas. Dia pun berharap keadaan tersebut akan tetap berlangsung demikian. Oleh karena itu wujud dari harapannya tersebut dia ujarkan melalui kata amin.

Pedagang sebagai manusia yang bertuhan meyakini akan adanya hubungan antara dia dengan Tuhan, antara dagangan dengan Tuhan. Pedagang membaca dengan peka akan adanya hubungan tersebut melalui dagangan yang dia peroleh dengan kualitas bagus serta ucapan dari pembeli yang memujinya. Mangunwijaya (1988:39) mengatakan agama atau religiusitas menumbuhkan kepekaan. Kepekaan dapat membantu seseorang meraih pengalaman religius dalam menangkap pesan atau tanda terselubung yang ada di sekitarnya. Religiusitas merupakan sesuatu yang sangat dalam, yang bersentuhan dengan keinginan seseorang, membutuhkan ketaatan dan memberikan imbalan atau mengingat seseorang dalam masyarakat.

\section{c. Hubungan manusia dengan lingkungan}

Hubungan manusia dengan lingkungan berkaitan dengan perkataan dan perbuatan manusia yang mendukung kebaikan lingkungan atas dasar religi. Masyarakat Banjar merupakan masyarakat yang beragama. Perkataan dan perbuataannya biasanya dilandaskan kepada ajaran agamanya termasuk dalam dunia transaksi. Contoh berikut merupakan gambaran yang dimaksud.

[13] maapai aku kada kawa manyumbalihakan minjangan ikam samalam, ladingku pas tumpul nah

"maaf ya aku tidak bisa menyembelihkan kijang kamu kemarin, pisauku sedang tumpul nah"

Data [13] menggambarkan adanya hubungan manusia dengan lingkungan berdasarkan religi. Latar peristiwa adalah kala itu pedagang kehilangan jualannya akibat tidak bisa menjual kijang yang sudah disembelih kepada pembeli. Alasannya adalah dia tidak bisa menyembelihkan kijang pesanan langganannya akibat pisaunya tumpul. Pedagang menjadi rugi satu hari karena tidak bisa berjualan.

Hubungan antara manusia dengan lingkungan tergambar dalam ucapan pedagang. Entah kenapa pisau yang biasanya digunakan oleh pedagang untuk menyembelih kijang hari itu tumpul tidak bisa digunakan seperti biasanya. Pembeli tampaknya memaklumi hal ter- 
sebut. Mereka berdua mengetahui apa yang diperintahkan oleh agama kalau mau menyembelih hewan. Pembeli menganggukan kepala kala pedagang berujar maapai aku kada kawa manyumbalihakan minjangan ikam samalam, ladingku pas tumpul nah. "Maaf ya aku tidak bisa menyembelihkan kijang kamu kemarin, pisauku sedang tumpul nah"

Hewan kijang adalah bagian dari lingkungan. Menurut ajaran agama jika ingin menyembelih hewan maka sebaiknya pisau yang digunakan dalam kondisi tajam jangan sampai tumpul apalagi berkarat. Pisau yang tumpul apalagi berkarat akan memperlambat kematian hewan. Hal itu berarti akan menyiksa hewan sebagai salah satu mahluk ciptaan Tuhan yang bisa merasakan Data [13] menggambarkan akan kereligiusan pedagang dalam bertransaksi. Dia tidak mementingkan keuntungan satu hari dengan menyembelih hewan menggunakan pisau tumpul. Pedagang memilih mengikuti ajaran agamanya daripada memperhitungkan keuntungan materi yang bisa dia dapatkan hari itu. Pedagang yakin akan bal asan yang dia terima jika menyembelih hewan dengan tidak semestinya.

[14] $\mathrm{N}$ ah aku kada manjual pidio nang kaya itu, cari ja di lain, takutan.

"Nah aku tidak menjual video yang seperti itu, cari saja di lain, takut".

Data [14] menggambarkan adanya hubungan manusia dengan lingkungan. Latar peristiwa dalam ujaran ini adalah ketika itu ada pembeli yang mencari video dewasa. Pedagang mendengar hal itu menjawab sebagaimana data [14].

Data ini menunjukkan adanya keyakinan pedagang akan kemampuan video dewasa yang akan merusak akhlak para penikmatnya. Dia juga takut akan dosa terhadap Tuhan. Video yang dijual nya sangat mempengaruhi alam pikiran para pembeli.

Hubungan antara manusia dengan lingkungan sangat diperhatikan pedagang. Ling- kungan yang dalam hal ini penikmat video yang didagangkannya merupakan mahluk Tuhan yang bisa hancur akibat pedagang yang tidak takut dosa. Oleh karena itu, sebagai manusia yang memiliki agama dan Iarangan berbuat maksiat, melalui perbuatannyalah pedagang tidak menjual barang yang berkaitan dengan maksiat.

Data [14] menjadi contoh dari sekian contoh bahwa pedagang tidak sekedar memikirkan untuk rugi dalam transaksi tapi dia juga memegang akan aturan dalam agamanya. A turan berlandaskan kereligiusan. Keriligiusan yang menjadikan pedagang tersebut peka akan akibat perbuatannya jika melanggar aturan bagi kehidupan di sekitarnya. Hal ini sesuai dengan apa yang dimaksudkan KBBI (2013: 1159) menyatakan religi berarti kepercayaan akan adanya kekuatan adikodrati di atas manusia. Mangunwijaya (1988:39) mengatakan agama atau religiusitas menumbuhkan kepekaan. Kepekaan dapat membantu seseorang meraih pengalaman religius dalam menangkap pesan atau tanda terselubung yang ada di sekitarnya. Religiusitas merupakan sesuatu yang sangat dalam, yang bersentuhan dengan keinginan seseorang, membutuhkan ketaatan, dan memberikan imbalan atau mengingat seseorang dalam masyarakat.

\section{PENUTUP}

Dari uraian di atas disimpulkan bahwa nilai moral tidak hanya didapatkan dari kajian karya sastra semata, tapi juga dapat dikaji dalam tuturan lisan masyarakat sehari-hari. Hasil analisis singkat di atasbahwa dalam tuturan transaksi jual-beli ini ditemukan: pertama, nilai moral berwujud nilai kejujuran, mandiri, tolong menolong, dan peduli; dan kedua nilai religi berwujud hubungan manusia dengan manusia, hubungan manusia dengan Tuhan, dan hubungan manusia dengan lingkungan. Nilai-nilai ini adalah bagian dari nilai kerohanian yang berasal dari hati nurani penutur bahasa tersebut. Nilai ini adalah bagian 
dari nilai budaya masyarakat Banjar di Kalimantan Selatan.

\section{DAFTAR PUSTAKA}

Aminuddin. 2009. Pengantar A presiasi Sastra. Bandung: Sinar Baru Algensindo

Bastian, Indra. 2006. A kuntansi Sektor Publik. Yogyakarta: Universitas Gajah Mada

Bryant, dkk. 2002. 16 M oral Dasar Bagi Anak. Jakarta: Gramedia

Djojosuroto, Kinayati. 2006. A nalisis Teks Sastra dan Pengajarannya. Yogyakarta: Penerbit Pustaka. Duta Wacana University Press.

Harianto. 2014. Pendekatan Pendidikan Berbasis N ilai Karakter dan Budaya di Perguruan Tinggi. Jogjakarta: FKIP UN Yogyakarta

Kaelan. 2010. Pendidikan Pancasila. Yogjakarta: Paradigma

Koentjaraningrat. 2014. Pengantar A ntropologi. Jakarta: Rineka Cipta

Mahsun. 2005. M etodologi Penelitian Bahasa. Jakarta: Raja Grafendo Perkasa

Makmurtomo. 1989. N ilai-N ilai M oral. Jakarta: Bal ai Pustaka

Nengsih, Sri Wahyu. 2013. Refleksi Budaya Banjar dalam Kumpulan Kisdap M alam Kumpai Batu. Bunga Rampai Sastra (7) 8099

Nengsih, Sri Wahyu. 2015. Gambaran Religiuitas Orang Banjar dalam M antra Banjar. Bunga Rampai Sastra (9) 92-108

Notonegoro. 1975. Pancasila Secara Utuh Populer. Jakarta: Pancoran Tujuh
Nurfaidah, Resti. 2015. A ngeline dalam Citangis Ratri. Jurnal Genta Bantera. Kepri (1) .(1) 7585

Nurgiyantoro, Burhan. 2007. Sastra Anak Pengantar Pemahaman Dunia Anak. Yogjakarta: Gajah Mada University Press Patricia, Nidya Triastuti. 2012. N ilai-nilai Budi Pekerti dalam Fabel Banjar. Banjarbaru: Balai Bahasa Provinsi Kalimantan Selatan

Qadtratilah, Mety Takdir. 2009. Tesaurus Bahasa Indonesia. Jakarta: PT Indah Jaya Adipratama.

Soekanto, Soerjono. 2014. Sosiologi Suatu Pengantar. Jakarta: PT Raja Grafindo Persada

Sudaryanto. 2015. M etode dan A neka Teknik A nalisis Bahasa. Jakarta: Sanata Darma University Pres

Suseno, Franz Magnis. 1987. Etika Jawa: Sebuah A nalisa Falsafi tentang Kebijaksanaan Hidup Jawa. Jakarta: Gramedia

Tim. 2008. Kamus Besar Bahasa Indonesia edisi IV . Jakarta: PT. Gramedia

Tim. 2015 Kamus Besar Bahasa Indonesia edisi V. Jakarta: PT.Gramedia.

Wijaya, Y.B. Mangun. 1988. Sastra dan Religiusitas. Jakarta: Kansius

Wiyono, Slamet. 2005. M emahami A kuntasi Syariah di Indonesia. Jakarta: Grasindo

Yulianto, Agus. 2012. A spek M oral dalam Sastra M adihin. Bunga Rampai Sastra (6) 70-95 